\title{
A Prova Penal e as Reformas do CPP
}

Antonio Milton de Barros

\section{RESUMO}

A modificação das leis sempre é reclamada, em razão das constantes mudanças sociais por que passa o país. Em relação ao Código de Processo Penal, além dessa exigência natural, por ser datado de 1941, a promulgação da Constituição Federal de 1988 expôs um grave conflito entre os dois diplomas, exigindo profundas mudanças ao Código, visando sua adequação à nova ordem constitucional. E, com efeito, importantes modificações foram introduzidas ao sistema processual, seja através de leis modificadoras ao texto do Código, a exemplo do não reconhecimento de presunção de citação, seja por meio de leis extravagantes, onde se destaca a criação dos Juizados Especiais Criminais, dentre outras. Posteriormente, diversos outros projetos foram apresentados com vistas a modificações pontuais ao Código, culminando com a apresentação de diversas leis modificadoras ao seu texto. Neste trabalho, serão apontadas e comentadas as principais modificações referentes à prova penal, verificadas nos anos de 2003 a 2009.

Palavras-chave: Constituição Federal, Código de Processo Penal, prova penal, reformas processuais.

\begin{abstract}
The modification in law is always claimed, due to the constant social changes by which the country goes through. In relation to the Penal Procedures Code, besides this natural demand, since it dates from 1941, the promulgation of the Federal Constitution of 1988 exposed a serious conflict between the two legal institutes, demanding profound changes to the Code, aiming at its adequacy to the new constitutional order. And, indeed, important modifications have been introduced to the procedural system, be it through the laws that modified the Code, such as the non recognition of the citation presumption, be it by means of supplementary laws, where the creation of the Special Criminal Courts stands out, among others. Afterwards, diverse other projects have been presented intending to perform punctual modifications in the Code, culminating with the presentation of diverse laws that modified its text. In this paper, the main changes concerning the penal proof verified between the years 2003 and 2009 will be pointed out and commented.
\end{abstract}

Keywords: Federal Constitution, Penal Procedures Code (CPP), penal proof, procedural reforms.

\section{Interrogatório do acusado}

1.1 Natureza jurídica do interrogatório

A defesa se apresenta sob duas formas: a primeira é a defesa técnica, realizada por advogado; a outra consiste na manifestação da própria pessoa acusada e é denominada de autodefesa. Nesse sentido, toda participação pessoal do acusado, inclusive o interrogatório, assume característica de defesa. No entanto, a natureza jurídica desse ato sempre se apresentou controvertida.

Historicamente, o interrogatório constituía forma de obtenção da mais importante das 
provas criminais, tida como a rainha das provas, a prova por excelência ${ }^{1}$; mas, paradoxalmente, essa prova, a confissão, era obtida de forma insidiosa, com ameaças e até mediante tortura, ou seja, sem qualquer garantia aos acusados.

E assim continuou, também no Brasil, até o advento de suas primeiras cartas políticas; desde a Constituição do Império, promulgada a 25.03.1824, ocorreu alguma evolução, sobretudo com o Código Criminal de 1832, mas ainda incipiente e objeto de críticas doutrinárias. Embora tenha o Código Criminal passado por profundas modificações, em 1841, o interrogatório não sofreu alterações, assim acontecendo com as legislações que se sucederam.

Quanto ao Código de 1941, Espínola Filho² o considerava como uma peça de defesa, mas, também, como uma franca oportunidade de obtenção de prova, aliás, como consta da Exposição de Motivos do próprio Código. Camargo Aranha ${ }^{3}$ afirmou que "inegavelmente, diante da lei processual em vigor, é um meio de prova, tanto que serve como alicerce condenatório, funcionando, acidentalmente como meio de defesa".

O interrogatório funcionava, então, como meio de defesa e meio de prova, ou como meio de defesa e fonte de prova, eis que o acusado tinha a oportunidade de oferecer sua versão, ao tempo em que o juiz observava-o e colhia outros dados de que necessitava para aferir sua responsabilidade e dosar a pena a ser-lhe aplicada. Essa postura sofreu considerável alteração, em face do disposto no art. $5^{\circ}$, LXII, da Constituição de 1988, que reconheceu o direito ao silêncio, passando a ser visto mais meio de defesa.

Reformado, em 2003, através da Lei 10.792, o Código aproximou-se dos ditames constitucionais. Com essa reforma, afirmando-se como um ato facultativo, tendo em vista o direito ao silêncio, o interrogatório assume a feição de autêntico meio de defesa. Entretanto, é de se ressalvar a hipótese de o acusado optar por responder às perguntas formuladas. Nesse caso, além de constituir-se em manifestação da autodefesa, será também oportunidade de obtenção de prova, ainda que apenas de interesse da defesa.

Mais recentemente, a Lei n. 11.719/08, ao prever que o interrogatório seja o último ato da instrução, consolida o posicionamento de que se trata de ato preponderantemente de defesa, pois se o acusado manifestar o desejo de falar, terá conhecimento das demais provas. Recorde-se que anteriormente o interrogatório era o primeiro ato da instrução, tanto no processo comum e como no júri.

\footnotetext{
${ }^{1}$ BIASOTTI, Carlos. A confissão judicial. Boletim IBCCRIM, São Paulo, n. 13, p. 2, fev. 1994.

${ }^{2}$ ESPINOLA FILHO, Eduardo. Código de Processo Penal brasileiro. Rio de Janeiro: Borsoi, 1955.

${ }^{3}$ ARANHA, Adalberto Camargo. Da prova no processo penal. São Paulo: Saraiva, 1944.
} 


\title{
1.2 Lei 10.792/03
}

A Lei 10.792 , de $1^{\circ}$ de dezembro de 2003, introduziu alterações nos arts. 185 a 196, do CPP, objetivando dar cumprimento aos princípios constitucionais da ampla defesa, direito ao silêncio e contraditório.

\begin{abstract}
Art. 185, caput: $O$ acusado que comparecer perante a autoridade judiciária, no curso do processo penal, será qualificado e interrogado na presença de seu defensor, constituído ou nomeado.

$\S 1 .^{\circ} O$ interrogatório do acusado preso será feito no estabelecimento prisional em que se encontrar, em sala própria, desde que estejam garantidas a segurança do juiz e auxiliares, a presença do defensor e a publicidade do ato. Inexistindo a segurança, o interrogatório será feito nos termos do Código de Processo Penal.

$\S 2 .^{\circ}$ Antes da realização do interrogatório, o juiz assegurará o direito de entrevista reservada do acusado com seu defensor.
\end{abstract}

Em primeiro lugar, destaca-se a obrigatoriedade da presença do defensor ao ato do interrogatório, que não constava da redação original do CPP, conquanto tal exigência pudesse ser extraída diretamente da Constituição, desde 1988. Além disso, está prevista a possibilidade de entrevista reservada do defensor com o interrogando. A eficácia dessa última previsão dependerá da postura do advogado nomeado, pois, em geral, a nomeação será feita no momento do interrogatório, de forma que ele precisará exigir a concessão de prazo para sua realização.

Sobre o interrogatório em estabelecimento prisional, surgiram controvérsias. De um lado, sustentou-se que a regra fere a publicidade que deve nortear os atos processuais, salientando-se que eventual restrição apenas pode ser permitida quando indispensável para a preservação da intimidade ou do interesse público ( $\mathrm{CF}$, art., $\left.5^{\circ} \mathrm{LX}\right)$, a ser analisada caso a caso. Assim, "a restrição de maneira geral e indiscriminada da publicidade de ato que, em sua essência deve ser aberto a acompanhamento pelo povo, além de suprimir do exame judicial a verificação de sua pertinência no caso concreto, torna inviável o controle difuso do exercício da atividade jurisdicional". Por isso, tais atos seriam nulos. ${ }^{4}$

Com o devido respeito a essa conclusão, penso que a previsão legal não dispensa a análise de cada caso, minimizando o risco de nulidade e contornando os transtornos decorrentes da necessidade de se transportar os réus presos para serem interrogados.

Contudo, conforme era previsível não se tem notícia de que os juízes saiam de seus gabinetes, onde possuem melhor estrutura e mais conforto, para realizar interrogatórios em presídios. Há dificuldade, também, para os deslocamentos dos advogados e promotores. De

\footnotetext{
4 PITOMBO, Cleunice Valentim Bastos e outros, Publicidade, ampla defesa e contraditório no novo interrogatório judicial. Boletim IBCCRIM, São Paulo, n. 135, p. 2, fev. 2004.
} 
qualquer modo, essa forma obviaria o risco de fuga, sem a necessidade de adoção de outras medidas mais gravosas, como o interrogatório à distância, de que se falará a seguir.

\subsection{Interrogatório por vídeo-conferência}

Após a entrada em vigor da Lei 10.792/03, reaparece no cenário a discussão sobre o interrogatório à distância (ou on line), que constava do projeto de lei, mas que não integrou o texto aprovado. Em alguns Estados, a matéria foi regulamentada e aplicada durante algum tempo. No Estado de São Paulo, foi aprovada a Lei n. 11.819, de 5 de janeiro de 2005, que foi declarada inconstitucional, pelo Supremo Tribunal Federal, notadamente por questão de incompetência legislativa, em razão de ser matéria de competência legislativa da União.

Logo em seguida, foi aprovada e entrou em vigor a Lei n. 11.900, de 11 de janeiro de 2009, que alterou o art. 185 do CPP, dando-lhe a seguinte redação:

185: o acusado que comparecer perante a autoridade judiciária, no curso do processo penal, será qualificado e interrogado na presença de seu defensor, constituído ou nomeado.

$\S I^{o}$ O interrogatório do réu preso será realizado, em sala própria, no estabelecimento em que estiver recolhido, desde que estejam garantidas a segurança do juiz, do membro do Ministério Público e dos auxiliares bem como a presença do defensor e a publicidade do ato.

$\S 2^{\underline{o}}$ Excepcionalmente, o juiz, por decisão fundamentada, de ofício ou a requerimento das partes, poderá realizar o interrogatório do réu preso por sistema de videoconferência ou outro recurso tecnológico de transmissão de sons e imagens em tempo real, desde que a medida seja necessária para atender a uma das seguintes finalidades:

I - prevenir risco à segurança pública, quando exista fundada suspeita de que o preso integre organização criminosa ou de que, por outra razão, possa fugir durante o deslocamento;

II - viabilizar a participação do réu no referido ato processual, quando haja relevante dificuldade para seu comparecimento em juízo, por enfermidade ou outra circunstância pessoal;

III - impedir a influência do réu no ânimo de testemunha ou da vítima, desde que não seja possível colher o depoimento destas por videoconferência, nos termos do art. 217 deste Código;

IV - responder à gravíssima questão de ordem pública.

$\S 3^{\underline{o}}$ Da decisão que determinar a realização de interrogatório por videoconferência, as partes serão intimadas com 10 (dez) dias de antecedência.

$\S 4^{o}$ Antes do interrogatório por videoconferência, o preso poderá acompanhar, pelo mesmo sistema tecnológico, a realização de todos os atos da audiência única de instrução e julgamento de que tratam os arts. 400, 411 e 531 deste Código.

$\S 5^{\circ}$ Em qualquer modalidade de interrogatório, o juiz garantirá ao réu o direito de entrevista prévia e reservada com o seu defensor; se realizado por videoconferência, fica também garantido o acesso a canais telefônicos reservados para comunicação entre o defensor que esteja no presídio e o advogado presente na sala de audiência do Fórum, e entre este e o preso.

$\S 6^{\circ}$ A sala reservada no estabelecimento prisional para a realização de atos processuais por sistema de videoconferência será fiscalizada pelos corregedores e pelo juiz de cada causa, como também pelo Ministério Público e pela Ordem dos Advogados do Brasil. 
$\S 7^{0}$ Será requisitada a apresentação do réu preso em juízo nas hipóteses em que o interrogatório não se realizar na forma prevista nos $\$ \S 1^{\underline{o}}$ e $2^{\underline{o}}$ deste artigo.

$\S 8^{o}$ Aplica-se o disposto nos $\S \S 2^{\circ}, 3^{\circ}, 4^{\circ}$ e $5^{\circ}$ deste artigo, no que couber, à realização de outros atos processuais que dependam da participação de pessoa que esteja presa, como acareação, reconhecimento de pessoas e coisas, e inquirição de testemunha ou tomada de declarações do ofendido.

$\S 9^{\underline{o}} \mathrm{Na}$ hipótese do $\S 8^{\underline{o}}$ deste artigo, fica garantido o acompanhamento do ato processual pelo acusado e seu defensor."

Portanto, foi introduzido o sistema de interrogatório por videoconferência, embora se possa esperar novos debates a respeito, pois quando declarou inconstitucional a lei paulista que autorizava o uso do sistema, nos autos de HC n. 88914/SP, o Supremo Tribunal Federal não se baseou apenas na questão da incompetência legislativa estadual, sendo levantados outros aspectos pelo relator, relativos a provável inconstitucionalidade material.

\section{Direito ao silêncio}

O artigo 186, com redação dada pela Lei 10.792/03, ficou assim:

Art. 186. Depois de devidamente qualificado e cientificado do inteiro
teor da acusação, o acusado será informado pelo juiz, antes de iniciar
$o$ interrogatório, do seu direito de permanecer calado e de não
responder perguntas que lhe forem formuladas.
Parágrafo único. O silêncio, que não importará em confissão, não
poderá ser interpretado em prejuízo da defesa.

Nada mais se fez do que "transportar" para o Código aquilo que a Constituição Federal preconizada, em seu artigo $5^{\circ}$, LXIII. Desde a promulgação da atual Carta Magna, não poderia ser interpretado literalmente o art. 186, na segunda parte, que valorava de forma negativa o silêncio do acusado.

\section{O contraditório no interrogatório}

De acordo com o art. 187 do Código, “O defensor do acusado não poderá intervir ou influir, de qualquer modo, nas perguntas e nas respostas”.

A não intervenção do defensor já motivou grande polêmica, pensando-se que a vedação era apenas para o defensor, na medida em que não se referia à acusação. No entanto, o princípio da isonomia indicava outro entendimento, ou seja, a participação ou a não participação no interrogatório deveria ser tratada igualmente em relação às duas partes. Antes de 1988, era mais aceitável que os representantes das partes não participassem. Após a promulgação da Constituição, o melhor entendimento recomendava a participação de ambos. Mas, em regra, vedava-se que tivessem participação ativa. Ignorava-se o texto constitucional. Após a Lei 10.792/03, não se discutiu mais essa questão, pois o artigo 188 reza: “Após 
proceder ao interrogatório, o juiz indagará das partes se resta algum fato para ser esclarecido, formulando as perguntas correspondentes se o entender pertinente e relevante" ${ }^{\circ}$.

\section{Procedimento do interrogatório}

$\mathrm{O}$ art. 187, com a redação dada pela Lei 10.792, dispõe que o interrogatório será constituído de duas partes: sobre a pessoa do acusado e sobre os fatos. Na verdade, são três partes $^{6}$, sendo a primeira de qualificação, a segunda de individualização e a terceira de mérito.

Após a qualificação, o acusado é indagado sobre aspectos profissionais, familiares e sociais e vida pregressa criminal. Trata-se, enfim, de se colher informações que deveriam originar de investigação, inclusive com o concurso de profissionais especializados, como assistentes sociais e psicólogos, para uma adequada individualização da pena. Equivale ao preenchimento de boletim de vida pregressa, que a polícia faz questionando o próprio acusado. Bem por isso, segundo me parece, desde esse momento deve ser preservado o direito constitucional ao silêncio, exatamente pelo fato de se poder extrair daí elementos para a fixação da pena ou sua forma de cumprimento. Se lhe é facultado omitir a verdade sobre os fatos, o acusado pode, também, não querer referir-se a questões de sua vida pessoal e de seu passado. Contudo, prevalece o entendimento de que essas são perguntas de resposta obrigatória.

Por último, passa-se ao interrogatório referente ao fato (ou interrogatório de mérito), quando são formuladas perguntas sacramentais, relacionadas no parágrafo segundo do dispositivo. É certo que o juiz não está vinculado a essas perguntas, podendo e, por vezes, até mesmo devendo formular outras, exceto no caso de o acusado optar pelo silêncio. Caso o acusado negue a acusação, poderá prestar esclarecimentos e indicar provas (art. 189). Se a confessar, será indagado sobre os motivos e circunstâncias do fato e se outras pessoas concorreram (art. 190).

\section{Sistemas de avaliação da prova}

\subsection{Sistema da prova legal}

Com base no sistema da prova legal, cada prova tinha o seu valor predeterminado; os juízes deviam examinar o caráter da prova e extrair dela o respectivo valor, para os fins de decisão; havia regulamentação para cada meio de prova; para ser aceita a prova testemunhal,

\footnotetext{
${ }^{5}$ O que constava do art. 187, passou, após a reforma de 2003, a ser tratado pelo art. 188 e vice-versa.

${ }^{6}$ NUCCI, Guilherme de Souza. Manual de processo e execução penal. São Paulo: Revista dos Tribunais, 2005, p. 392.
} 
exigia-se o mínimo de duas testemunhas, com base no brocardo testis unus, testis nullus; eram feitas inquirições sucessivas e estavam impedidas algumas pessoas, devido ao parentesco com o acusado, o sexo, ou a classe social ${ }^{7}$.

Havia a crença da intervenção de divindade em favor de quem estivesse com a razão, cabendo ao juiz apenas apreciar e declarar o resultado. Em tal sistema o juiz manifestava a verdade não de acordo com a convicção resultante das provas, mas sim de conformidade com o valor legal. É a consagração do princípio da certeza moral do legislador.

\subsection{Sistema da livre apreciação ou íntima convicção}

Esse sistema confere ao julgador total e irrestrita possibilidade de coligir e apreciar as provas. Nele, o legislador nada diz sobre o valor das provas. A admissibilidade, seu carreamento para os autos e a avaliação, enfim tudo é deixado a cargo do juiz ${ }^{8}$. O juiz não se vincula a qualquer regra legal, pois a verdade jurídica é ditada apenas pela sua convicção, resultante não só dos elementos fornecidos como também de seu conhecimento pessoal, de suas impressões, de informações extra processo etc.; não está sequer obrigado a motivar sua decisão. Vigora o princípio da certeza moral do juiz.

Por haver dado margem a despotismo judicial, foram colocadas as seguintes barreiras contra a absoluta liberdade de julgar: a) a possibilidade de um reexame do que fora decidido; b) o estabelecimento do princípio segundo o qual o que não está escrito no processo não pertence ao mundo; c) a instituição da prova legal, fato que restringiu a possibilidade de livre apreciação das provas.

O sistema da íntima convicção é adotado, entre nós, no julgamento pelo Tribunal do Júri, já que os jurados votam os quesitos de forma secreta, não tendo o dever de fundamentar sua escolha. "O encontro da vontade do conselho de sentença decorre da identificação da vontade da maioria dos jurados, expressada na votação isolada dos quesitos e na votação inteira do questionário" 9 .

\subsection{Sistema da livre convicção ou da persuasão racional}

Sem o perigo do despotismo judicial do sistema da íntima convicção e sem tolher o juiz do poder de investigar a verdade, como ocorria com o sistema das provas legais, surge o

\footnotetext{
${ }^{7}$ GOMES FILHO, Antonio Magalhães. Direito à prova no processo penal. São Paulo, Revista dos Tribunais, 1997, p. 23.

8 TORNAGHI, Hélio. Curso de processo penal. 7. ed. São Paulo: Saraiva, 1990.1990, p. 274.

9 PORTO, Hermínio Alberto Marques, Júri - Procedimento e Aspectos do Julgamento - Questionários, 4. ed., São Paulo, Revista dos Tribunais, 1984. p. 146.
} 
sistema da livre convicção ou do livre convencimento, admitindo, de modo geral, todos os meios de prova.

Assim, dos dois sistemas anteriores, evoluiu-se para o moderno sistema da persuasão racional que, ao mesmo tempo em que mantém a liberdade de apreciação, vincula o convencimento do juiz ao conjunto probatório coligido e constante dos autos, obrigando-o a fundamentar sua decisão, para se poder aferir seu raciocínio e as razões de seu convencimento.

O juiz age livremente na apreciação das provas (convicção), porém sua avaliação deve ser ajustada às regras científicas (jurídicas, lógicas e experimentais) preestabelecidas (condicionadas). Daí, também, o nome de sistema de convicção condicionada ou da persuasão racional. Há a obrigatoriedade de fundamentar e motivar a decisão para que se saiba quais as condicionantes que levaram o julgador à convicção dos fatos, para se aquilatar o acerto ou desacerto da decisão ${ }^{10}$.

\subsection{O sistema brasileiro e a Lei 11.690/08}

Art. 155. O juiz formará sua convicção pela livre apreciação da prova produzida em contraditório judicial, não podendo fundamentar sua decisão nos elementos exclusivamente informativos colhidos na investigação, ressalvadas as provas cautelares, não repetiveis $e$ antecipadas.

Parágrafo único. Somente quanto ao estado das pessoas serão observadas as restrições estabelecidas na lei civil.

Pela redação do art. 155, modificada pela Lei 11.690, de 09/06/2008, fica claro que as provas, para serem aptas e capazes de servir ao convencimento do juiz, devem ser colhidas sob a garantia do contraditório, de forma que não são aceitas para o fim de decidir o processo as provas colhidas na fase de investigação. Excetuam-se apenas as provas produzidas antecipadamente, as cautelares e as irrepetíveis, sobre as quais se estabelecerá o contraditório posterior.

Pelo que se vê, continuará o processo a acolher provas realizadas fora do contraditório efetivo, contentando-se com o chamado contraditório diferido ou postergado. E isso ocorre justamente em relação às provas mais importantes, as perícias, que são mais acreditadas, porque oriundas de técnicos. Essa questão poderá ser solucionada no projeto de lei sobre a investigação criminal, se for admitida a defesa na fase de investigação.

\footnotetext{
${ }^{10}$ ARANHA, Adalberto José Q. T. Camargo, Da Prova no Processo Penal, São Paulo, Saraiva, 1994. p. 58.
} 
A reforma "não teve coragem para romper com a tradição brasileira de confundir atos de prova com atos de investigação, com graves reflexos na eficácia probatória deles" "11. E, para agravar, o legislador acrescentou a expressão "exclusivamente" ao dispositivo em questão, anulando a proibição do uso de prova realizada no inquérito policial e, portanto, fora do contraditório. Isto é, a prova pode ser usada para fundamentar a decisão judicial, desde de que não esteja isolada.

Isso neutraliza a própria redação do art. 155 , no sentido de que as provas, para serem aptas e capazes de servir ao convencimento do juiz, devem ser colhidas com as garantias do contraditório, com exceção das provas produzidas antecipadamente, as cautelares e as não repetíveis, sobre as quais se estabelecerá o contraditório posterior.

Comentando esse tópico da reforma, Marcos Zilli ${ }^{12}$, apesar de aplaudir a nova lei, também critica a postura legislativa nesse particular, afirmando:

\begin{abstract}
Mas, a coesão de um modelo processual de partes foi comprometida. Isso porque a proibição total de inserção dos elementos informativos no campo cognitivo, desenhada pela proposta original da Comissão de Reforma, foi sensivelmente abrandada. Pela versão aprovada, fica o juiz autorizado a buscar naqueles elementos o reforço para certas provas produzidas em contraditório, confirmando assim a veracidade de uma das teses. Mais lógico seria que o conflito resultante das provas divergentes, não superável pela possibilidade de obtenção de novas provas, levasse à absolvição do acusado e não à invocação de elementos colhidos unilateralmente.
\end{abstract}

É certo que Código de Processo Penal consagra a liberdade de apreciação da prova, mas a análise do art. 155, notadamente em confronto com a Constituição Federal (art. 93, IX), leva à conclusão de que o sistema adotado é o da persuasão racional, com o dever de fundamentar as decisões. A exceção está no Tribunal do Júri, que decide por convicção íntima, sem o dever de fundamentar, em virtude do sigilo das votações (CF, art. 5o, XXXVIII). Há, também, resquício da prova legal, na exigência de exame de corpo de delito nas infrações que deixam vestígios e na indispensabilidade de prova documental, quando a questão se refere ao estado das pessoas (CPP, arts. 155, parágrafo único, e 158). Item para conclusão

\title{
6. Ônus da prova
}

\subsection{Conceito}

\footnotetext{
${ }^{11}$ LOPES JUNIOR, Aury. Bom para quê (m)? Boletim do IBCCRIM, ano 16, n. 188, julho 2008, p. 09.

${ }^{12} \mathrm{O}$ pomar e as pragras. Boletim IBCCRIM, ano 16, n. 188, jul. 2008, p. 2.
} 
A palavra ônus tem origem latina e significa fardo, carga, peso, imposição etc. Daí porque ônus da prova (onus probandi). Segundo Barbosa Moreira ${ }^{13}$, há ônus quando o exercício de uma faculdade é condição para se obter uma determinada situação de vantagem ou para impedir uma situação desvantajosa.

A prova não constitui uma obrigação ou um dever e sim um ônus, um encargo. O dever existe para com outrem; quem o tem e não cumpre sofre pena; o encargo é uma obrigação para consigo mesmo; se a lei encarrega alguém de praticar um ato, em seu próprio benefício, e o encarregado não o realiza, a ninguém prejudica, senão a si mesmo; por isso não sofre pena; deixa de lucrar o que ganharia se o praticasse; por exemplo: se o réu num processo penal tem um documento que lhe prova a inocência, é de toda vantagem para ele juntá-lo aos autos; caso não o faça, pode não ser reconhecida sua inocência, mas não há lei alguma que lhe imponha o dever de apresentar o documento e o ameace de pena pelo simples fato de não o fazer ${ }^{14}$.

O ônus propicia a alternativa ao titular, que poderá atendê-lo ou não; se não o fizer sofrerá o prejuízo decorrente de sua inação; de outro lado, a obrigação emerge de um comando legal que o obrigado tem o dever de cumprir.

\section{2 Ônus objetivo e ônus subjetivo}

Em seu aspecto objetivo, o ônus da prova prescinde de qualquer atividade das partes, constituindo tarefa do juiz, quando estiver em dúvida no momento de julgar. O juiz deve, $a$ priori, levar em consideração toda a prova produzida, independentemente de quem a tenha produzido. Em seguida, poderá utilizar-se de seus poderes instrutórios, com vistas a esclarecer a verdade. No aspecto subjetivo, o ônus dirige-se às partes, como encargo que lhes cabe de buscar as fontes de prova e introduzi-las no processo, pelos meios de prova.

Visto de outro modo, o juiz não tem propriamente ônus, mas dever funcional de julgar; o ônus objetivo equivale ao princípio da comunhão da prova, também denominado princípio da aquisição da prova.

6.3 Ônus da prova e obrigatoriedade de defesa.

A lei penal obriga o acusado a se defender, tanto que ao contumaz e ao que não tem advogado é dado defensor dativo; e a falta do exercício de defesa importa em nulidade

\footnotetext{
13 BADARÓ, Gustavo Henrique Righi Ivahy. Ônus da prova no processo penal. São Paulo: Revista dos Tribunais, 2003. p. 171.

${ }^{14}$ TORNAGHI, Hélio. Curso de processo penal. 7. ed. São Paulo: Saraiva, 1990. p. 306.
} 
absoluta. Mas, isso não desfigura o ônus probatório porque a obrigação existente é de ser defendido (a prática de atos necessários, presença às audiências, acompanhamento das provas, alegações finais etc.); mas, a produção de prova é apenas um ônus, e, como tal, quem não a realiza de forma alguma viola o princípio da obrigatoriedade da defesa.

Portanto, a realização da defesa constitui obrigação processual, mas a produção de provas não, e, conseqüentemente, não haverá nulidade pela não produção de provas, como haveria em caso de não se realizar efetivamente a defesa.

\subsection{Divisão do ônus da prova}

A lei processual penal disciplina que "a prova da alegação incumbirá a quem a fizer" (CPP, art. 156, caput, primeira parte), mas não estabelece, devidamente, os critérios para essa divisão, quanto ao que devem as partes alegar, o que compete à acusação e o que cabe à defesa, gerando perplexidade e divergência de posicionamentos.

A doutrina e a jurisprudência, na interpretação do art. 156, seguem a doutrina de Carnelutti, para quem "cabe provar a quem tem interesse de afirmar; portanto, a quem apresenta uma pretensão cumpre provar-lhe os fatos constitutivos e a quem fornece a exceção cumpre provar os fatos extintivos ou as condições impeditivas ou modificativas" $"$.

Assim, caberia ao acusador o ônus de provar os fatos constitutivos, que dizem respeito à tipicidade (existência de um fato considerado ilícito penal) e à autoria (a realização do fato por ação atribuível ao denunciado). E ao acusado os fatos extintivos, ou seja, os que têm a eficácia de fazer cessar a relação jurídica (por ex.: a prescrição, a decadência etc.); os impeditivos, que excluem o elemento vontade livre e consciente (erro de fato, coação irresistível, as causas de exclusão da culpabilidade etc.) e os modificativos, que dão um novo aspecto ao fato (ex. a exclusão de antijuridicidade).

Com relação à culpabilidade, considera-se que a culpa em sentido estrito necessita ser demonstrada pela acusação, tanto que é requisito da denúncia a especificação de sua forma: negligência, imprudência ou imperícia. O dolo é considerado presumido diante da experiência de que os atos praticados pelo homem são conscientes e voluntários, cabendo ao réu demonstrar o contrário. Portanto, o acusado, em regra, é que se esforça por demonstrar não ter agido dolosamente.

\footnotetext{
${ }^{15}$ ARANHA, Adalberto José Q. T. Camargo, Da Prova no Processo Penal, São Paulo, Saraiva, 1994.
} 
Contudo, Tourinho ${ }^{16}$ afirma que à parte acusadora cabe provar tanto o fato e a autoria como o elemento subjetivo, dolo ou culpa, "pois, se o réu goza da presunção de inocência, é evidente que a prova do crime deve ficar a cargo da acusação".

Afrânio Jardim ${ }^{17}$ acrescenta a necessidade de se atentar, também, para o princípio in dubio pro reo, que é negado quando se atribui à acusação apenas o ônus de provar a prática pelo réu de uma conduta típica. Esse modo de ver não harmoniza o art. 156 com a aplicação desse princípio, que exige exclusivo e completo esforço de convencimento por parte da acusação; do contrário o acusado será absolvido por falta de provas (CPP, art. 386, VI). Devese levar em conta que o acusador, ao demonstrar positivamente que o fato se passou como denunciado (aí se incluindo dolo, culpa e ausência de justificativas), estará afastando o que a defesa alegou, por incompatibilidade entre as duas versões, nada restando ao réu provar.

$\mathrm{E}$, de fato, essa deve ser a conclusão. O ônus da prova efetivamente cabe à parte acusadora (MP ou querelante), em razão do princípio segundo qual deve ser absolvido em caso de dúvida (in dubio pro reo). Todavia, se o réu quiser uma absolvição cujo resultado se projete favoravelmente sobre os efeitos civis da sentença penal absolutória, terá cabalmente de fazer a sua prova, pois nesse caso o benefício da dúvida não o favorecerá.

\subsection{Faculdade probatória do juiz no CPP de 1941}

A segunda parte do art. 156, do CPP, antes da reforma operada em 2008, dispunha: “mas, o juiz poderá, no curso da instrução ou antes de proferir sentença, determinar, de ofício, diligências para dirimir dúvida sobre ponto relevante”. Essa disposição sempre se mostrou controvertida. De um modo geral, entendia-se que às partes cabia oferecer espontaneamente a prova dos fatos que alegassem, em seu próprio interesse, facultando-se ao juiz, supletivamente, a fim de apurar a verdade, chamar para si a tarefa de demonstrar o que uma das partes não quis, não soube, ou não pôde fazer.

Mas, em sentido oposto, Geraldo Prado ${ }^{18}$ considera que a autorização contida no dispositivo comentado representa violência ao sistema acusatório; por conferir ao juiz direito que é das partes, conexo ao direito de ação e de defesa, e também "por colocá-lo na difícil posição de investigador imparcial, na medida em que todo investigador parte de uma premissa, que aceita como verdadeira, a ela se vinculando psicologicamente". O autor cita como exemplo a pesquisa de provas que sequer foram consideradas pelo órgão de acusação,

\footnotetext{
16 TOURINHO FILHO, Fernando da Cosa. Processo penal. Vol. 1, 25. ed. São Paulo: Saraiva, 2003.

${ }^{17}$ JARDIM, Afrânio Silva. Direito processual penal. 6. ed., Rio de Janeiro: Forense, 1997. p. 205.

18 PRADO, Geraldo Sistema acusatório: a conformidade constitucional das leis processuais penais. Rio de Janeiro: Lumen Juris, 2001.
} 
ao qual, nestas circunstâncias, o juiz acaba por substituir. Com isso, ele se afastará da posição de distanciamento das partes e de seus interesses, posição esta apta a permitir a melhor ponderação e conclusão.

No entanto, Prado entende que visando à implementação de poderes de assistência ao acusado, o juiz pode pesquisar, de forma supletiva, provas da inocência, de acordo com tese esposada pela defesa; essa postura se justificaria em razão de ser o acusado destinatário de posição favorável abrigada no seio do sistema acusatório, sendo que "o destinatário da posição jurídica favorável não pode ser prejudicado pela aplicação, contra si mesmo, daquele benefício instituído pela Constituição".

Scarance Fernandes ${ }^{19}$ leciona que a igualdade processual impõe que o autor e réu deverão ter os mesmos direitos, mesmos ônus e mesmos deveres. Contudo, ressalva que a exigência de tratamento paritário entre as partes "não exclui a possibilidade de, em determinadas situações, dar-se a uma delas tratamento especial para compensar eventuais desigualdades, suprindo-se o desnível da parte inferiorizada a fim de, justamente, resguardar a paridade de armas". O tratamento diferenciado em favor da defesa está justificado, segundo o Scarance, pelos princípios in dubio pro reo e favor rei.

A nosso ver, a atuação do juiz, ainda que em favor do acusado, afronta o sistema acusatório e a isonomia processual. A inegável desigualdade entre a acusação e a defesa, tendo em vista o aparelhamento estatal de que se vale o órgão oficial da acusação, poderá ser contornada no momento da sentença, com aplicação, pelo juiz, dos princípios acima referidos (in dubio pro reo e favor rei).

Assim, o art. 156, em sua segunda parte, e todos aqueles dispositivos de conteúdos semelhantes, reclamavam uma adequação à ordem constitucional.

6.6 A faculdade probatória do juiz na reforma processual de 2008

Como mencionado, a questão referente à faculdade probatória do juiz sempre foi controvertida. A redação do art. 156, modificada pela Lei 11.690/2008, ampliou essa possibilidade, conforme texto transcrito abaixo:

Art. 156. A prova da alegação incumbirá a quem a fizer, sendo, porém, facultado ao juiz de ofício:

I- ordenar, mesmo antes de iniciada a ação penal, a produção antecipada de provas consideradas urgentes e relevantes, observando a necessidade, adequação e proporcionalidade da medida;

II - determinar, no curso da instrução, ou antes de proferir sentença, a realização de diligências para dirimir dúvida sobre ponto relevante.

\footnotetext{
${ }^{19}$ FERNANDES, Antonio Scarance. Processo penal constitucional. São Paulo: Revista dos Tribunais, 1999.
} 
As considerações formuladas com referência ao texto anterior do art. 156, cuja redação não incluía o que consta do inciso I acima transcrito, denotavam a controvérsia. $O$ fato de a reforma não haver alterado a sistemática anterior não apenas reacendeu o debate doutrinário, como acrescentou novas críticas, exatamente em razão da faculdade constante do primeiro inciso. De fato, pela nova redação, o juiz não apenas mantém aquelas prerrogativas, como pode determinar, de ofício, a realização de provas consideradas urgentes e relevantes, antes do início da ação penal.

Aury Lopes $\mathrm{Jr}^{20}$ assinalou que "o art. 156 sempre foi um grande problema, especialmente para aqueles comprometidos com o sistema acusatório-constitucional, incrivelmente, ficou pior!".

Mesmo quem entende admissível a produção de prova, pelo juiz, critica a nova redação do dispositivo:

\begin{abstract}
Aqui vale registrar nossa discordância com os que sustentam não caber ao juiz natural da causa qualquer iniciativa probatória, mesmo no curso da instrução criminal. É preciso distinguir: se ainda não há imputação, não há processo e, portanto, são impertinentes e atentatórias à imparcialidade e ao modelo acusatório as iniciativas judiciais tendentes a, durante as investigações inquisitoriais e sem provocação do interessado, buscar provas. ${ }^{21}$
\end{abstract}

Nessa mesma linha, Marcos Zilli ${ }^{22}$, que também concorda com a atividade instrutória judicial, justificando-a como "condição indispensável para a adequada e justa prestação jurisdicional e para a composição dos interesses públicos contrastantes que permeiam o processo penal", não poupa críticas ao legislador, quando diz:

Indesejado, entretanto, é o poder inserto no inciso I do artigo 156 o qual permite a determinação, de ofício, mesmo antes de iniciada a ação penal, da produção de provas antecipadas. A previsão, se mal conduzida, pode levar o juiz ao perigoso terreno da atuação investigatória subvertendo-se, assim, o sentido de um processo penal de matriz acusatória.

O mais razoável seria admitir, assim mesmo em caráter excepcional, a iniciativa do juiz isto é, sem requerimento expresso de uma das partes, a realização de prova apenas em relação aos fatos já discutidos no processo, em que constem as fontes de prova sobre as quais terá lugar a posterior atividade probatória, e desde que vislumbrada a possibilidade de que

\footnotetext{
${ }^{20}$ LOPES JUNIOR, Aury. Bom para quê (m)? Boletim do IBCCRIM, ano 16, n. 188, julho 2008, p. 09.

${ }^{21}$ CRUZ, Rogério Schietti Machado. Com a palavra, as partes. Boletim do IBCCRIM, ano 16 - n. 188 - julho de 2008, p. 17-18.

${ }^{22}$ ZILLI, Marcos. O pomar e as pragras. Boletim do IBCCRIM, ano 16, n. 188, julho 2008.
} 
possa contribuir para a busca da verdade processual. Pelo que se vê, a reforma do processo penal de 2008 traçou caminho oposto a esse objetivo, por isso já se vê questionada ${ }^{23}$.

\title{
7. $\mathrm{O}$ direito à prova e a questão das provas ilícitas
}

\subsection{Direito à prova}

O direito à prova insere-se no quadro das garantias do devido processo legal e liga-se ao direito de ação e de defesa e à atividade jurisdicional, pois de nada adiantaria a autor e réu o direito de trazer a juízo suas alegações se não lhes fosse proporcionada oportunidade no desenvolvimento da causa de demonstrar suas afirmações ${ }^{24}$.

Também o juiz tem importante papel na produção da prova. Para que possa proferir decisão justa e conforme a realidade, além de se dotar o juiz de poderes instrutórios, assegurase a sua efetiva participação na produção da prova: a ele incumbe garantir às partes a plenitude do direito à prova, dele depende a profundidade da colheita do material probatório. Por outro lado,

\begin{abstract}
a garantia do contraditório não tem apenas como objetivo a defesa entendida em sentido negativo - como oposição ou resistência -, mas sim principalmente a defesa vista em sua dimensão positiva, como influência, ou seja, como direito de incidir ativamente sobre o desenvolvimento e o resultado do processo; o direito à prova assume a maior relevância em relação ao contraditório, uma vez que a atividade probatória representa o momento central do processo: estritamente ligada à alegação e à indicação dos fatos, visa ela a possibilitar a demonstração da verdade, revestindo-se de particular relevância para o conteúdo do provimento jurisdiciona ${ }^{25}$.
\end{abstract}

Desse modo, "o concreto exercício da ação e da defesa fica essencialmente subordinado à efetiva possibilidade de se representar ao juiz a realidade do fato posto como fundamento das pretensões das partes, ou seja, destas poderem servir-se das provas". E a exigência do contraditório, na formação e produção das provas, se desdobra nos seguintes aspectos: a) a proibição de utilização de fatos que não tenham sido previamente introduzidos pelo juiz no processo e submetidos a debate pelas partes; b) a proibição de utilizar provas formadas fora do processo ou de qualquer modo colhidas na ausência das partes; c) a obrigação do juiz, quando determine a produção de provas ex-officio, de submetê-las ao

\footnotetext{
${ }^{23}$ BARROS, Antonio Milton de. A reforma do CPP sobre provas. Reafirmação do sistema inquisitivo. Disponível em <http://jus2.uol.com.br/doutrina/texto.asp?id=11571>. Acesso em 06ago2008.

${ }^{24}$ FERNANDES, Antonio Scarance. Processo penal constitucional. São Paulo: Revista dos Tribunais, 1999. p. 66.

${ }^{25}$ Ada Pellegrini Grinover, Antonio Magalhães Gomes Filho e Antonio Scarance Fernandes. Nulidades no processo penal. 3. ed. São Paulo: Malheiros, 1993. pp. 104-105
} 
contraditório das partes, as quais devem participar de sua produção e poder oferecer a contraprova $^{26}$.

Em conseqüência, pode ser viciada tanto a prova que for colhida sem a presença do juiz, como a colhida pelo juiz, sem a presença das partes, exigindo-se, pois, a concomitante presença de ambos - juiz e partes. E sempre que não se assegure a plenitude de liberdade de atuação das partes, em matéria probatória, pode configurar-se cerceamento de defesa ou de acusação.

\subsection{Limites ao direito à prova}

Assim como os direitos do homem não podem ser entendidos de maneira absoluta, também o direito à prova não é absoluto; a restrição natural decorre da necessidade de se garantir a convivência social. Além disso, o processo deve pautar-se dentro de certos parâmetros, em que não se admitem meios de prova moralmente ilegítimos e atentatórios contra as liberdades do indivíduo e o interesse social. São exemplos dessas limitações o dever de sigilo, a prerrogativa dos acusados de não auto-incriminação e a proibição das provas ilícitas. Destas exceções, apenas a questão da prova ilícita foi objeto de reforma.

\subsection{Proibição de provas ilícitas}

A Constituição Federal, no art. 5. ${ }^{\circ}$, LVI dispõe: "são inadmissíveis, no processo, as provas obtidas por meios ilícitos". Essa regra é o resultado de opção do constituinte por uma das correntes doutrinárias existentes. Uma delas entendia que as provas teriam validade, ou não, independentemente da ilicitude da obtenção, devendo a ilicitude ser apurada e punida separadamente, sem, contudo, contaminar a prova. A segunda corrente propugnava que a obtenção ilícita da prova poderia levar à sua ilicitude e conseqüente inadmissibilidade, mas desde que o bem jurídico sacrificado com a ilicitude tenha sido um bem de maior valor que o bem obtido com a apresentação da prova, obedecendo a um critério de proporcionalidade. Finalmente, aparecia um terceiro grupo de doutrinadores entendendo que a obtenção ilícita sempre contamina a prova, impedindo sua apresentação e validade judicial.

A Constituição, como se vê, optou pela terceira corrente. Na verdade, o legislador constituinte não se contentou em coibir o uso de prova ilícita ou forjada, mas também buscou vedar a obtenção irregular de prova; isso porque há elementos de prova que, originalmente, não podem ser considerados ilícitos, mas dependendo da forma como foram obtidos podem

\footnotetext{
${ }^{26}$ Id. Ibid.
} 
tornar-se inquinados de vícios. Trata-se da prova ilícita por derivação, isto é, aquela situação em que a prova em si é licita, mas consiste em informação extraída de uma prova obtida por meio ilícito; é caso, por ex., de confissão mediante tortura, em que o acusado indica onde se encontra o produto do crime; ou na interceptação telefônica não autorizada, através da qual se venha a conhecer provas que, colhidas licitamente, levem à apuração do crime. Trata-se da teoria dos frutos da árvore envenenada, segundo a qual o vício da planta se transmite a todos os seus frutos.

Em virtude de a Constituição não se referir expressamente à prova ilícita por derivação, existia certa divergência doutrinária e até mesmo jurisprudencial sobre sua aceitação, ou não, no processo. No entanto, a reforma introduzida ao Código de Processo Penal, pela Lei n. 11.690/08, alterou a redação do art. 157, passando a regular a matéria:

\begin{abstract}
Art. 157. São inadmissíveis, devendo ser desentranhadas do processo, as provas ilícitas, assim entendidas as obtidas em violação a normas constitucionais ou legais.

$\S 1^{\circ}$ São também inadmissíveis as provas derivadas das ilícitas, salvo quando não evidenciado o nexo de causalidade entre umas e outras, ou quando as derivadas puderem ser obtidas por uma fonte independente das primeiras.

$\S 2^{\circ}$ Considera-se fonte independente aquela que por si só, seguindo os trâmites típicos e de praxe, próprios da investigação ou instrução criminal, seria capaz de conduzir ao fato objeto da prova.

$\S 3^{\circ}$ Preclusa a decisão de desentranhamento da prova declarada inadmissivel, esta será inutilizada por decisão judicial, facultado às partes acompanhar o incidente.

$\S 4^{\circ} O$ juiz que conhecer do conteúdo da prova declarada inadmissivel não poderá proferir a sentença ou acórdão (VETADO).
\end{abstract}

Antes de comentar o texto legal ora transcrito, salienta-se que a doutrina distingue a prova ilícita da ilegítima. A prova é ilícita quando obtida com violação a regras de direito material e ilegítima quando obtida com infração a regras de direito processual. As consequiências são distintas. No caso da prova ilegítima, o encaminhamento da questão será com base no tema das nulidades processuais, enquanto que a prova ilícita deverá ser desentranhada do processo, conforme dispõe a redação renova do art. 157.

A reforma visou adequar o art. 157 ao texto constitucional, fixando, também, na lei processual penal, as balizas da regra constitucional de exclusão das provas ilícitas, em qualquer hipótese, ou seja, "conceituando-as e tomando posição quanto à proibição de sua utilização, mesmo quando se trate da denominada prova ilícita por derivação, ou seja, da prova não ilícita por si mesma, mas conseguida por intermédio de informações provenientes de provas ilicitamente colhidas". ${ }^{27}$

\footnotetext{
${ }^{27}$ CF exposição de motivos do projeto que resultou na lei 11.690/08.
} 
Esta última hipótese cuida da teoria dos "frutos da árvore envenenada", cujo aproveitamento também se afasta, em princípio. Portanto, a reforma constituiu avanço, pois não apenas determinou a rejeição da prova ilícita, como sua exclusão do processo.

Entretanto, a questão ainda está sujeita a crítica. Primeiro, porque ficou a possibilidade de se utilizar essa prova derivada, quando não evidenciado o nexo de causalidade ou na hipótese de o juiz considerar que a prova seria obtida por outro modo.

Considera-se que não haverá nexo de causalidade quando, por exemplo, após uma atividade ilegal dos agentes policiais, a prova surgir por outro ato não ligado à ilicitude.

No tocante à fonte independente, há duas teorias a respeito, ambas baseadas em precedentes da justiça norte-americana. Uma é a chamada teoria da fonte independente (independent source), que prevê possibilidade de co-existirem duas fontes de obtenção da prova, uma delas ilícita. Ex. uma busca legal ou outra ilegalmente realizada. E a outra a da exceção da descoberta inevitável (inevitable discovery), que autoriza a admissibilidade da prova derivada da ilícita, se no caso concreto ela seria descoberta de qualquer maneira. Ex. a polícia interrompe as investigações quando estava próxima ao esclarecimento do fato, porque alguém obteve a confissão do suspeito mediante coação ${ }^{28}$.

Em segundo lugar, a crítica doutrinária direciona-se à adoção do entendimento jurisprudencial que restringe o alcance do princípio da contaminação, consistente no contra o veto ao $§ 44^{\circ}$. Estes parágrafo tinha como finalidade evitar a contaminação do julgador. Citase como exemplo a hipótese de o juiz tomar conhecimento de prova incriminadora, através de conversa telefônica obtida ilegalmente. Mesmo reconhecida posteriormente a ilicitude dessa prova, o juiz manterá em seu inconsciente o conhecimento daquela prova, que poderá influenciar sua decisão. Apesar do veto, há entendimento doutrinário no sentido tornar-se impedido de sentenciar o juiz que tomar conhecimento de prova ilícita. Apesar de considerar correta essa posição, parece-nos de difícil aplicação prática, por enquanto.

No campo das provas ilícitas, realça-se a questão referente ao princípio da proporcionalidade, segundo o qual, havendo conflito entre dois princípios (no caso de dois princípios fundamentais), um deve ser privilegiado em detrimento de outro. Assim, a prova

\footnotetext{
${ }^{28}$ DEZEM, Guilherme Madeira. Da prova Penal. Campinas-SP: Milennium, 2008. pp. 135-137. Como esclarece Cleunice Pitombo (2008), "O problema surge ao se admitir, na persecução penal, a prova de "fonte independente" ( $\$ 2^{\circ}$, art. 157). O legislador ordinário restringiu a norma constitucional — mais abrangente —, apresentando texto vago e genérico de duvidosa constitucionalidade. Caberá, agora, ao aplicador da lei e ao intérprete fixar-lhe, ou não, a incidência"
} 
ilícita seria admitida desde que para preservar um bem jurídico de valor igual ou mais relevante.

O princípio da proporcionalidade, em sentido estrito, determina que se estabeleça uma correspondência entre o fim a ser alcançado por uma disposição normativa e o meio empregado; isso significa, acima de tudo, que não se fira o "conteúdo essencial de direito fundamental, com desrespeito intolerável do valor/princípio que o define: a dignidade humana..." ${ }^{29}$. Na hipótese de conflitos entre princípios (e direitos) constitucionalmente assegurados, o princípio da dignidade humana figura como limite, justificando, e até exigindo, a imposição de restrições a outros bens constitucionalmente protegidos, na medida em que tais direitos não possuem caráter absoluto ${ }^{30}$.

A doutrina e a jurisprudência, em regra, não admitem a prova ilícita sequer em face do princípio da proporcionalidade, isto é, mesmo quando se cuida da apuração de infrações muito graves. Contudo, admite-se com menor ressalva a prova ilícita pro-reo, prevalecendo o princípio da inocência e a liberdade individual, em detrimento do poder punitivo estatal, o que não deixa de ser um aspecto do princípio da proporcionalidade. Sua aceitação se justificaria sob a ótica do direito de defesa, em nome do princípio denominado de favor rei. Especialmente, quando se trata de prova produzida pelo próprio acusado. Entende-se que, nesse caso, a ilicitude é eliminada por causas legais, como a legítima defesa, que exclui a antijuridicidade. Trata-se, em fim, de uma causa de exclusão da ilicitude, caso em que a prova não pode mais ser considerada ilícita. ${ }^{31}$.

\section{O princípio da oralidade e a identidade física do juiz}

Com pequena variação, a doutrina aponta os seguintes princípios da prova penal: princípio da auto-responsabilidade das partes; princípio da audiência contraditória; princípio da não auto-incriminação; princípio da publicidade e princípio da oralidade. Para os propósitos deste trabalho, que visa enfocar as reformas processuais relativas à prova, interessa abordar apenas o último, em relação ao qual ocorreu modificação.

$\mathrm{O}$ modo ou linguagem do procedimento pode ser escrito, oral ou misto. $\mathrm{Na}$ esfera do processo penal brasileiro, conquanto se apregoe a predominância do sistema oral, na verdade

\footnotetext{
${ }^{29}$ GERRA FILHO, Willis Santiago. Sobre os princípios constitucionais gerais: isonomia e proporcionalidade. Revista dos Tribunais. Ano 84, vol. 719, set. de 1995, p. 58.

${ }^{30}$ S ARLET, Ingo Wolfgang. A eficácia dos direitos fundamentais. 2. ed., Porto Alegre: Livraria do Advogado, 2001. p. 115.

${ }^{31}$ Nesse sentido, Ada Pellegrini Grinover, Antonio Magalhães Gomes Filho e Antonio Scarance Fernandes. Op. cit., p.116.
} 
existe um sistema misto, escrito e oral. Assim, os depoimentos são feitos oralmente, mas sempre reduzidos a termo escrito.

O princípio da oralidade engloba outros princípios, como concentração dos atos processuais e identidade física do juiz. Pelo princípio da concentração se busca concentrar toda a produção da prova em uma única ou em poucas audiências. E a exigência de que o juiz que preside a instrução deve proferir a sentença, isto é, o princípio da identidade física do juiz, passou a ser previsto no art. $399 \S 2 .^{\circ}$, do Código de Processo Penal pela Lei 11.719, de 20.06.2008. Essa lei ampliou, também, o sistema da oralidade e o da concentração, nos procedimentos comuns.

\section{Prova pericial}

\subsection{Conceito e natureza jurídica de perícia}

Perícia é a prova destinada a levar ao juiz elementos instrutórios sobre normas técnicas e sobre fatos que dependam de conhecimento especial. Trata-se de exame procedido por pessoa que tenha determinados conhecimentos técnicos, científicos, artísticos ou práticos acerca de fatos, circunstâncias ou condições pessoais inerentes ao fato punível, a fim de comprová-los.

Apesar da colocação no Código, que faz da perícia uma prova nominada como as demais, ela ostenta uma natureza jurídica que ultrapassa a condição de simples meio probatório, para atingir uma posição intermediária entre a prova e a sentença, pelos seguintes motivos: a) a função do perito não se esgota com a reprodução tão-só do que constatou com os seus conhecimentos especializados; ele emite um juízo de valor; b) a perícia é sempre prospectiva, porque também elabora prognósticos e avalia consequiências; as provas são retrospectivas, isto é, apenas se reportam ao passado; c) todas as provas são objetivas, ao passo que a perícia é eminentemente subjetiva, exatamente, por conter um juízo de valor, como mencionado $\operatorname{acima}^{32}$.

9.2 Exame de corpo de delito, dos instrumentos do crime e do local do fato

Certos delitos deixam vestígios materiais, como a lesão corporal, o homicídio etc.; outros não os deixam, como ocorre com os cometidos verbalmente (calúnia, difamação, injúria). Para os primeiros, dispõe o Código que será indispensável o exame de corpo de delito, cominando sua falta com a sanção de nulidade (art. 564, III, b). O exame de corpo de delito constitui-se em uma espécie do gênero da prova pericial.

\footnotetext{
32 ARANHA, Adalberto José Q. T. Camargo. Op. cit., p. 141.
} 
O corpo de delito é o conjunto de vestígios e sinais deixados pela infração penal; eles constituem a materialidade do delito. "Vestígios são sinais, dados materiais, resquícios perceptíveis pelos sentidos, manifestações físicas que se ligam a um ato ou fato ocorrido ou cometido, isto é, a infração penal. A apreciação, pelos sentidos, desses dados materiais é que constitui o exame de corpo de delito"33.

Contudo, há que se distinguir o exame de corpo de delito do exame dos instrumentos do crime, que são aqueles usados para a realização do crime, os objetos de que se serve o agente para delinqüir. Além do exame de corpo de delito, o Código exige também o exame desses, conforme dispõe o art. 175: "serão sujeitos a exame os instrumentos empregados para a prática da infração, a fim de se lhes verificar a natureza e a eficiência”.

Por conseguinte, enquanto o exame de corpo de delito tem por objetivo demonstrar a existência do crime, o exame dos instrumentos funciona como elemento avaliador da periculosidade do agente e indicador da dosagem da pena a ser aplicada.

O exame do local tem superior importância, sobretudo em determinados crimes, como o homicídio, por exemplo. $\mathrm{O}$ art. 169 determina que se preserve o local para que os peritos procedam ao levantamento do "estado das coisas", anotando as alterações ocorridas e as consequiências destas em relação ao fato.

Denotando a importância desse exame e da preservação do local, a redação original do Código foi alterada, pela Lei 8.862, de 28.03.94, no sentido de outorgar aos peritos criminais a decisão sobre a liberação do local do fato e dos objetos a este relacionados. Em primeiro lugar, deve a autoridade policial dirigir-se ao local e providenciar para que não se altere o estado de conservação das coisas, até a chegada dos peritos criminais. De outro lado, a autoridade policial só pode apreender os objetos que tiverem relação com o fato, após a liberação pelos peritos (CPP, art. 6. ${ }^{\circ}$ I e II).

\subsection{Exame de corpo de delito direto e indireto e prova testemunhal}

Em regra, o exame é feito diretamente no objeto ou pessoa que constitui o corpo de delito (o cadáver, uma janela arrombada etc). Entretanto, quando isso não é possível, admitese o exame de corpo de delito indireto (art. 158).

Na realidade, nesse último caso, não há propriamente "exame" pericial ou de corpo de delito. Os peritos, com base em seus conhecimentos, opinam à vista dos elementos de que disponham como filmes, fotografias, objetos encontrados e até mesmo a ficha de atendimento

\footnotetext{
${ }^{33}$ BORGES DA ROSA, Inocêncio. Processo penal brasileiro, Porto Alegre: Globo, 1942. p. 452.
} 
médico-hospitalar; esta última é a forma mais comum, porque as vítimas, mesmo quando não comparecem, nem são levadas às repartições policiais, normalmente, passam por ambulatórios ou hospitais, para atendimento médico.

Pode ocorrer de a testemunha relatar ao perito as circunstâncias do fato, para que este ofereça uma conclusão. Assim, se as testemunhas descreverem para os peritos tudo aquilo que estes, graças a seus conhecimentos técnicos, sabem ser sintomas de envenenamento, por determinada substância, podem eles concluir a respeito da causa mortis, em exemplo de Hélio Tornaghi $^{34}$.

Entretanto, quando não é possível a realização de exame diretamente no objeto que constitui o corpo de delito e nem existe qualquer elemento para que os peritos possam se basear, admite-se a prova testemunhal (CPP, art. 167). É o exemplo clássico do desaparecimento do cadáver. O dispositivo não deve ser invocado para aqueles casos em que o desaparecimento dos vestígios ocorreu por omissão ou desídia de órgãos estatais.

Não se afigura correto considerar essa hipótese como "exame de corpo de delito indireto"; na verdade, não pode ser considerado exame, que efetivamente não houve. A comprovação da materialidade se faz por meio de prova testemunhal, ou seja, sem a realização de exame e sem um parecer pericial. O próprio juiz se baseia na informação da testemunha, para formar sua convicção. Trata-se de uma exceção ao que dispõe o art. 158, do $\mathrm{CPP}^{35}$.

\subsection{Perito oficial, perito nomeado e assistente}

A perícia deve ser realizada por peritos oficiais, como regra. Esses peritos pertencem ao quadro de funcionários públicos, que tendo sido submetidos a concursos específicos de peritos criminais, são investidos legalmente e contratados por ato de governo, e, portanto, não dependem de nomeação da autoridade policial ou do juiz (CPP, art. 159, caput). Como exceção, onde não há peritos oficiais, a lei admite que a perícia seja realizada por pessoas idôneas, escolhidas preferencialmente dentre as que detenham conhecimentos específicos relacionados com a natureza do exame. Os peritos não oficiais são nomeados e compromissados para o ato que devem realizar (CPP, art. $159, \S \S 1^{\circ}$ e $2^{\circ}$ ).

No regime do CPP, os peritos são considerados auxiliares da Justiça, estando submetidos à disciplina judiciária (arts. 275 e seguintes), sendo que as partes não podem

\footnotetext{
${ }^{34}$ Apud TOURINHO FILHO, Fernando da Costa. Op.cit., p. 248.

${ }^{35}$ Nesse sentido, também se posiciona NUCCI, Guilherme de Souza. Manual de processo e execução penal. São Paulo: Revista dos Tribunais, 2005. p. 362.
} 
intervir na nomeação (art. 276). Contudo, a reforma processual introduzida pela Lei n. 11.690/08 adotou a figura do assistente. De acordo com o $§ 3 .^{\circ}$, do art. 159 , serão facultadas ao Ministério Público, ao assistente de acusação, ao ofendido, ao querelante e ao acusado a formulação de quesitos e indicação de assistente técnico.

Entretanto, o sistema continuará contentando-se com o chamado contraditório diferido ou postergado, em relação às perícias. Porque a possibilidade de indicação de assistentes técnicos, pelas partes, não configura a adoção do contraditório efetivo, tendo em vista que estes apenas atuarão depois de admitidos pelo juiz e após a conclusão dos exames e elaboração do laudo pelos peritos oficiais (art. $\left.159 \S 44^{\circ}\right)^{36}$. Ressalte-se que a regulamentação do contraditório nas perícias era um dos declarados propósitos da reforma ${ }^{37}$. Essa questão poderá ser solucionada pelo projeto de lei sobre a investigação criminal, se adotar, como previsto, a participação da defesa nessa fase procedimental.

As partes poderão também requerer a intimação dos peritos para esclarecerem a perícia e a responderem a quesitos (art. 159 § 5. ${ }^{\circ}$ ).

\section{Confissão}

10.1 Conceito, natureza jurídica e valor probatório

No campo do direito processual penal, a confissão é o reconhecimento realizado em juízo, por uma das partes, a respeito da veracidade dos fatos que lhe são atribuídos e capazes de ocasionar-lhe conseqüências jurídicas desfavoráveis. Portanto, sua natureza é de um meio de prova.

Quanto ao valor probatório, considera-se que a confissão, embora importante, não tem valor absoluto, devendo ser confrontada com as demais provas (art. 197) ou mesmo confirmada, quando se tratar de infração que deixa vestígios (art. 158).

A experiência tem demonstrado que à confissão não se pode nem se deve, em princípio, atribuir absoluto valor probatório. Circunstâncias várias podem levar um indivíduo a reconhecer-se culpado de uma infração que realmente não praticou: desejo de encontrar a morte (nos países que admitem a pena capital); enfermidade mental; interesse pecuniário; para proteger o verdadeiro criminoso; para ocultar crimes mais graves etc ${ }^{38}$.

\footnotetext{
${ }^{36}$ BARROS, Antonio Milton de. A reforma do CPP sobre provas. Reafirmação do sistema inquisitivo. Disponível em <http://jus2.uol.com.br>. Acesso em 06ago2008.

${ }^{37}$ Pierpaolo Cruz Bottini. Aspectos Gerais da Reforma Processual. Boletim do IBCCRIM, ano 16, n. 188, julho 2008, pp. 26-27.

${ }^{38}$ TOURINHO FILHO, Fernando da Costa. Op.cit., p. 286.
} 
10.2 Delação ou chamada de co-réu

Aurélio define delatar como denunciar como autor de um crime ou denunciar como culpado. Nesse sentido, a delação, ou chamamento do co-réu, consiste na hipótese em que um interrogando indica seu parceiro de crime, isto é, quando um acusado, sem negar a autoria, indica um comparsa ou partícipe do mesmo crime. Ou, então, simplesmente transfere a responsabilidade para outrem, ou seja, não assume a autoria e indica outro como verdadeiro autor.

Gabriel De Inellas, com apoio em julgados do Tribunal de São Paulo, afirma que "só se pode falar em delação quando o réu também confessa, porque, se negar a autoria, atribuindo-a a outrem, estará escusando-se da prática criminosa, em verdadeiro ato de defesa e, portanto, o valor da assertiva, como prova, será nenhum". E completa: "Dessarte, o elemento subjetivo essencial da delação, para sua credibilidade como prova, é a confissão do delator,"39.

No entanto, penso que a própria etimologia do vocábulo indica a possibilidade de abranger, também, a hipótese de o delator não confessar. Aliás, o Código de Processo Penal prevê ambas as situações: a) "se o interrogando negar a acusação, no todo ou em parte, poderá prestar esclarecimentos e indicar provas" (art. 189); b) "se confessar a autoria, será perguntado sobre os motivos e circunstâncias do fato e se outras pessoas concorram para a infração e quais sejam" (art. 190). Em qualquer caso, como a própria confissão (CPP, art. 197), a delação terá valor relativo e sempre dependerá da verossimilhança e dos detalhes contidos na narrativa, que poderão ou não ser confirmados.

Para a aceitação dessa prova será imperioso que se propicie a efetiva garantia do contraditório; devem estar presentes ao ato o delatado e seu defensor. Ou pelo menos este, se for observado o disposto no art. 191, que determina a separação dos interrogandos; apesar de que a separação dos acusados poderá ser dispensável, tendo em vista que, no caso, um dos acusados estará servindo como "testemunha".

\subsection{Delação premiada}

A delação premiada consiste em uma transação, em que o delator recebe algum benefício do Estado, para colaborar com a investigação, visando ou o esclarecimento de um crime, ou a minimização de suas conseqüências.

\footnotetext{
${ }^{39}$ INELLAS, Gabriel C. Zaccarias de. Da prova em matéria criminal, São Paulo: Juarez de Oliveira, 2000. P.
} 93. 
É variada a legislação sobre delação premiada; surgiu com a Lei n. 8.072/90 (art. 7. ${ }^{\circ}, \S$ 4. ${ }^{\circ}$ ), para os casos de seqüestro praticado por quadrilha, cujo dispositivo foi revogado pela Lei n. 9.269/96, que introduziu alterações no art. 159, do Código Penal; posteriormente, a Lei n. 9.034/95 previu redução de pena para a colaboração na hipótese de crimes praticados em organizações criminosas; a Lei n. 9.080/95 acrescentou disposições premiais para os delitos contra o sistema financeiro e a ordem tributária; a Lei n. 9.613/98, relativa aos delitos de lavagem de dinheiro; por fim, de maneira mais ampla, disciplinou o tema a Lei n. 9.807/99, a qual deve ser analisada em primeiro lugar, na aferição da medida.

De acordo com o art. 13, da Lei n. 9.807/90, da Lei n. 9.807, de 13.07.1999, o acusado primário que colaborar efetiva e voluntariamente com a investigação e o processo criminal, de forma a resultar na identificação dos demais co-autores ou partícipes da ação criminosa, na localização da vítima com sua integridade preservada e a recuperação total ou parcial do produto do crime, poderá obter o perdão judicial e a conseqüente extinção da punibilidade; de outro lado, o art. 14, da mesma lei dispõe: "o indiciado ou acusado que colaborar voluntariamente com a investigação policial e o processo criminal na identificação dos demais co-autores ou partícipes do crime, na localização da vítima com vida e na recuperação total ou parcial do produto do crime, no caso de condenação, terá a pena reduzida de um a dois terços".

Crítico do instituto, Édson Baldan ${ }^{40}$ afirma que, ao longo da história, o Direito Penal brasileiro foi dotado de normas premiais nas hipóteses de reconciliação ativa de caráter substancial; isto é, quando o autor de uma conduta típica agisse voluntariamente para evitar ou minorar a violação do bem jurídico por ele mesmo promovida, nas modalidades de desistência e do arrependimento voluntário. Entretanto, "mais recentemente, foi a legislação brasileira inundada de dispositivos que valorizam do agente uma contra-conduta que não incide, pelo menos diretamente, sobre o plano da ofensa, resolvendo-se, antes, na colaboração processual...”. Essa postura, segundo Baldan, além de eticamente reprovável, revela-se contraproducente, pois, interrompe uma cultura de aprimoramento investigativo, partindo do crime para o criminoso e não o inverso. Deveria, então, ser utilizada apenas nos casos extremos, para salvar a vida de um seqüestrado ou como ponto de partida de investigação, não como seu ponto final e prova direta.

40 BALDAN, Édson Luis. O jogo matemático da delação e da extorsão da prova mediante seqüestro do investigado. Boletim do IBCCRIM, ano 13, n. 159, p. 6, fev./2006. 
Na verdade, o instituto o instituto delação premiada recebe também outras críticas, do ponto de vista ético ${ }^{41}$, processual $^{42}$ e constitucional ${ }^{43}$. Mas, vários autores posicionam-se favoravelmente à sua aplicação, afirmando que pode constituir-se em arma eficaz no combate ao crime organizado, como ocorreu em outros países.

\section{Perguntas ao ofendido}

\subsection{Conceito de ofendido}

Considera-se ofendido ou vítima de crime "toda pessoa física ou jurídica e ente coletivo prejudicado por um ato ou omissão que constitua infração penal, levando-se em conta as referências feitas no conceito de crime pela criminologia" ${ }^{\text {"4 }}$.

Existe uma distinção conceitual conforme a natureza do crime. É chamado ofendido, nos crimes contra a honra e contra os costumes; lesado, nos crimes patrimoniais; vítima nos crimes contra a pessoa; vítima e prejudicado, nos crimes de homicídio, em que a vítima é o morto e prejudicado o que dele dependia financeiramente ${ }^{45}$.

Ofendido é, pois, o sujeito passivo imediato (eventual) da ação criminosa. Não é parte no processo, mas não pode ser considerado como uma testemunha, por não ser desinteressado. Portanto, não é computado no rol de testemunhas e não tem as mesmas obrigações delas, pois não presta compromisso e nem se sujeita a processo por falso testemunho. Pode responder por crime de denunciação caluniosa, se der causa à investigação criminal (abertura de inquérito ou de processo) contra alguém, imputando-lhe crime de que sabe ser inocente.

\subsection{Valor probatório}

O ofendido é sujeito da relação jurídico-material; suas palavras devem ser vistas com reservas, tendo em visa que não presta declarações sob compromisso e não está sujeito ao crime de falso testemunho. Assim, sua versão deve ser confrontada com os demais elementos de convicção, por se tratar de parte interessada no desfecho do processo. Entretanto, presumese que não tenha interesse em prejudicar um inocente ou mesmo acrescentar acusações ao culpado, devendo, em princípio merecer crédito como meio de prova.

\footnotetext{
${ }^{41}$ GARCIA, Roberto Soares. Delação premiada: ética e moral, às favas. Boletim do IBCCRIM, ano 13, n. 159, p. 2 , fev./2006.

${ }^{42}$ PRADO, Geraldo. Da delação premiada. Aspectos de direito processual. Boletim do IBCCRIM, ano 13, n. 159 , p. 10 , fev./2006

${ }^{43}$ COUTINHO, Jacinto Nelson de Miranda. Fundamentos à inconstitucionalidade da delação premiada. Boletim do IBCCRIM, ano 13, n. 159, p. 7, fev./2006

${ }^{44}$ OLIVEIRA, Ana Sofia Schmidt de. A vítima e o direito penal, São Paulo: Revista dos Tribunais, 1999. p. 87.

${ }^{45}$ GRECO, Alessandra Orcesi Pedro. A autocolocação da vítima em risco. São Paulo: Revista dos Tribunais, 2004. p. 17.
} 


\subsection{Obrigatoriedade ou não da oitiva do ofendido}

Não é pacífica, na doutrina e na jurisprudência, a questão da obrigatoriedade da convocação do ofendido para depor e também de que seja obrigado a se manifestar, quando chamado. Uma corrente considera que sua oitiva decorre do disposto no art. 201, mencionando que será ouvida sempre que possível. Nesse caso, isto é, sendo possível, nem mesmo precisaria ser requerida sua oitiva. Outros entendem que a ausência de requerimento torna-se desnecessária ou facultativa a oitiva. Mas, havendo requerimento, torna-se imprescindível sua intimação, caso em que não poderá deixar de atender, sob pena de ser conduzido coercitivamente.

De fato, de acordo com o $\S 11^{\circ}$, do art. 201, "se, intimado para esse fim, deixar de comparecer sem motivo justo, o ofendido poderá ser conduzido à presença da autoridade”. Mas, apesar disso, seguimos a orientação que considera que o ofendido tenha direito e não obrigação de ser ouvido no processo, em respeito à sua autonomia de vontade. Tanto que não há sanção quando ele se omite durante sua oitiva em juízo.

Segundo Guilherme Dezem Madeira ${ }^{46}$, "caso a vítima não deseje depor, e mantida a orientação atual, ela será conduzida até a audiência, mas, simplesmente, poderá ficar inerte e nenhuma consequiência penal poderá a ela ser imposta". Além de compartilhar desse entendimento, penso que não poderia sequer haver condução coercitiva, no caso de não comparecimento, o que já representaria desrespeito à vontade da vítima, pois se ela tem direito de ser ouvida, poderá exercê-la ou não. Mas, o legislador manteve a possibilidade de condução coercitiva, que certamente será utilizada na prática.

\subsection{O ofendido na Lei n. 11.690/08}

Art. $201 \ldots$

$\S 1 .^{\circ}$

$\S 2 .^{\circ}$ O ofendido será comunicado dos atos processuais relativos ao ingresso e à saída do acusado da prisão, à designação de data para audiência e à sentença e respectivos acórdãos que a mantenham ou modifiquem.

$\S 3 .^{\circ}$ As comunicações ao ofendido deverão ser feitas no endereço por ele indicado, admitindo-se, por opção do ofendido, o uso de meio eletrônico.

$\S 4 .^{\circ}$ Antes do início da audiência e durante a sua realização, será reservado espaço separado para o ofendido.

$\S 5 .^{\circ}$ Se o juiz entender necessário, poderá encaminhar o ofendido para atendimento multidisciplinar, especialmente nas áreas psicossocial, de assistência jurídica e de saúde, a expensas do ofensor ou do Estado.

\footnotetext{
46 DEZEM, Guilherme Madeira. Op. cit., pp. 230-233.
} 
$\S 6 .^{\circ}$ O juiz tomará as providências necessárias à preservação da intimidade, vida privada, honra e imagem do ofendido, podendo, inclusive, determinar o segredo de justiça em relação aos dados, depoimentos e outras informações constantes dos autos a seu respeito para evitar sua exposição aos meios de comunicação.

A reforma processual de 2008 acrescentou os parágrafos $2 .^{\circ}$ ao $6 .^{\circ}$ ao art. 201, permanecendo inalterado o caput e o antigo parágrafo único, que passou a ser o $\S 1 .^{\circ}$. Esses novos dispositivos preconizam um melhor tratamento à vitima do crime. Inicia-se pela obrigação de que seja comunicada sobre o andamento do processo, depois se recomenda que lhe seja reservado local separado e, por fim, que se resguarde o necessário sigilo, com vistas à preservação da intimidade. São medidas que, notoriamente, tendem a minimizar aquelas conseqüências que a criminologia denomina de vitimização secundária, decorrentes de pouco caso ou de maus tratos infligidos à vítima pelos agentes e funcionários de órgãos policiais.

A reforma se preocupou, ainda, com o espaço que o ofendido tinha com vistas à proteção de seus interesses particulares, como sujeito processual, pois, antes, aparecia no processo apenas como objeto de prova, dando seu 'testemunho' do crime ou submetendo-se a exame de corpo de delito, conforme o caso. Em geral, não recebia adequadas informações sobre o andamento do processo e, muitas vezes, sequer sobre seu resultado, exceto quando se habilitasse como assistente do Ministério Público.

\section{Prova testemunhal}

\subsection{Conceito}

Embora existam diversos conceitos de testemunha, na essência guardam o mesmo sentido. Em síntese, testemunha é a pessoa que declara em juízo seu conhecimento acerca dos fatos sobre os quais se litiga. Testemunho é o teor do depoimento, que é reduzido a termo, ou seja, transcrito em "Assentada", uma espécie de ata onde constam: lugar, dia, hora e pessoas presentes ao ato.

\subsection{Dever, dispensa e proibição de ser testemunha}

De acordo com o Código, em princípio, "toda pessoa tem capacidade para servir como testemunha" (art. 202), o que deve fazer mediante compromisso legal de dizer a verdade (art. 203). De acordo com o art. 206, a testemunha não pode eximir-se do dever de depor. O simples fato de silenciar pode configurar falso testemunho. Contudo, existem exceções ao dever de depor: a) os parentes do acusado podem ser dispensados (art., 206, $2^{\mathrm{a}}$ parte); b) outras pessoas são proibidas de depor porque são obrigadas a guardar sigilo, em virtude da 
função, ofício, ministério ou profissão, salvo se, desobrigadas, pelo interessado, quiserem fazê-lo (art. 207).

12.3 A prova testemunhal e as reformas processuais de 2008 e 2009

Com relação à prova testemunhal, ocorreram quatro modificações, com as recentes reformas processuais, sendo três através da Lei n. 11.690/08, nos arts. 210, 212 e 217.

A primeira destas consistiu na inclusão de um parágrafo ao art. 210, reforçando a necessidade de separação das testemunhas. Apesar da evidente boa intenção, dificilmente será possível cumprir tal propósito, por falta de adequada estrutura nos fóruns, com raras exceções. Em geral, o que se verifica é que as testemunhas (e até mesmo os acusados) chegam juntos e permanecem no mesmo espaço antes, durante e após as oitivas.

Quanto ao art. 212, foi abolido o sistema presidencialista de oitivas, segundo o qual as perguntas das partes e as respostas da testemunha eram feitas através do juiz. Pelo novo formato, cada parte tem o direito de fazer as perguntas aos depoentes sem a intermediação do juiz; quando a pergunta é dirigida à testemunha arrolada pelo indagador, fala-se em direct examination; quando se trata de perguntas à testemunha arrolada pela parte contrária, ocorre cross examination ou exame cruzado.

Ainda de acordo com o art. 212, o juiz poderá impedir que seja feita pergunta capaz de induzir a resposta da testemunha; ele pode também formular perguntas complementares ao final.

O art. 217 passou a ter a seguinte redação:

Art. 217. Se o juiz verificar que a presença do réu poderá causar
humilhação, temor, ou sério constrangimento à testemunha ou ao
ofendido, de modo que prejudique a verdade do depoimento, fará a
inquirição por videoconferência e, somente na impossibilidade dessa
forma, determinará a retirada do réu, prosseguindo na inquirição,
com a presença do seu defensor.
Parágrafo único. A adoção de qualquer das medidas previstas no
caput deste artigo deverá constar do termo, assim como os motivos
que a determinaram.

Nesse ponto, a reforma inovou no tocante à providência a ser tomada, quando houver risco de o depoente sentir-se intimidado em depor perante o acusado. Antes, apenas estava prevista a retirada deste da sala de audiências. Agora, menciona-se a possibilidade da teleaudiência ou videoconferência.

A última dessas modificações veio através da Lei n. 11.900/08, que incluiu o $\S 3$. $^{\circ}$ ao art. 222, facultando a oitiva também da testemunha por videoconferência, em vez de expedir carta precatória, quando ela residir fora da jurisdição processante. 


\section{Conclusões}

Como pode ser conferido no texto, vários foram os pontos reformados do Código de Processo Penal. Entretanto, tratando-se de reformas pontuais, não há perfeita unidade sistemática, o que é objeto de críticas doutrinárias, inclusive no que toca ao ponto principal, que é a busca de sintonia desse estatuto com a Constituição Federal. Comprova essa conclusão o fato de haver sido constituída nova comissão de juristas encarregados de propor um projeto de reforma de todo o Código.

\section{REFERÊNCIAS}

ALVES, Roque de Brito. Dos indícios no processo penal. Rio de Janeiro: Forense, 2003.

AQUINO, José Carlos G. Xavier de. A prova testemunhal no processo penal brasileiro, São Paulo, Saraiva,1994.

ARANHA, Adalberto José Q. T. Camargo, Da Prova no Processo Penal, São Paulo, Saraiva, 1994.

AVOLIO, Luiz Francisco Torquato. Provas ilícitas. 2. ed. São Paulo: RT, 1999.

BADARÓ, Gustavo Henrique Righi Ivahy. Ônus da prova no processo penal. São Paulo: Revista dos Tribunais, 2003.

BALDAN, Édson Luis. O jogo matemático da delação e da extorsão da prova mediante seqüestro do investigado. Boletim do IBCCRIM, ano 13, n. 159, fev.2006.

BARROS, Antonio Milton de. A reforma do CPP sobre provas. Reafirmação do sistema inquisitivo. Disponível em <http://jus2.uol.com.br>. Acesso em 06ago2008.

. Curso básico de processo penal. Franca-SP: Lemos e Cruz, 2007.

BOTTINI, Pierpaolo Cruz. Aspectos Gerais da Reforma Processual. Boletim do IBCCRIM, ano 16, n. 188, jul.2008.

BIASOTTI, Carlos. A confissão judicial. Boletim IBCCRIM. São Paulo, n.13, fev. 1994.

CHOUKR, Fauzi Hassan, Processo penal à luz da Constituição. São Paulo: Edipro, 1999.

COELHO, Walter. Prova indiciária em matéria criminal. Porto Alegre: Sergio Fabris, 1996.

COUTINHO, Jacinto Nelson de Miranda. Fundamentos à inconstitucionalidade da delação premiada. Boletim do IBCCRIM, ano 13, n. 159, fev.2006

CRUZ, Rogério Schieti Machado. Com a palavra, as partes. Boletim do IBCCRIM, ano 16 - n. 188 - jul.2008.

DEZEM, Guilherme Madeira. Da prova penal - tipo processual, provas típicas e atípicas. Campinhas-SP: Milenium, 2008. 
DINIZ, Maria Helena. Dicionário jurídico. Vol. 3. São Paulo: Saraiva, 1998.

ESPÍNOLA FILHO, Eduardo. Código de Processo Penal anotado. 3. ed., vol. I. Rio de Janeiro: Borsoi, 1954.

FERNANDES, Antonio Scarance. Processo penal constitucional. São Paulo: Revista dos Tribunais, 1999.

GARCIA, Roberto Soares. Delação premiada: ética e moral, às favas. Boletim do IBCCrim, ano 13 , n. 159, fev./2006.

GOMES FILHO Antonio Magalhães. Direito à prova no processo penal. São Paulo, Revista dos Tribunais, 1997.

GRECO, Alessandra Orcesi Pedro. A autocolocação da vítima em risco. São Paulo: Revista dos Tribunais, 2004.

GRECO FILHO, Vicente. Manual de processo penal. 6. ed. São Paulo: Saraiva, 1999.

GRINOVER, Ada Pellegrini, GOMES FILHO Antonio Magalhães \& Fernandes Antonio Scarance. Nulidades no processo penal. 3. ed. São Paulo: Malheiros, 1993.

GUERRA FILHO, Willis Santiago. Sobre os princípios constitucionais gerais: isonomia e proporcionalidade. In: Revista dos Tribunais. Ano 84, vol. 719, set. de 1995. p. 57

GUIDI, José Alexandre Marson. Delação premiada no combate ao crime organizado. FrancaSP: Lemos \& Cruz, 2006.

INELLAS, Gabriel C. Zaccarias de. Da prova em matéria criminal, São Paulo: Juarez de Oliveira, 2000.

JARDIM, Afrânio Silva. Direito processual penal. 6. ed., Rio de Janeiro: Forense, 1997.

LOPES JUNIOR, Aury. Bom para quê (m)? Boletim do IBCCRIM, ano 16, n. 188, julho 2008 .

MALATESTA, Nicola Framarino. A Lógia das Provas em Matéria Criminal. Tradução Waleska Girotto Silveberg(Trad.), São Paulo: Conam, 1995.

MARCÃO, Renato Flávio. Interrogatório: primeiras impressões sobre as novas regras ditadas pela Lei 10.792, de 1. ${ }^{\circ}$.12.2003. Disponível em: < http://www.ibccrim.org.br>. Acesso em 08.dez.2003.

MARQUES, José Frederico. Tratado de direito processual penal. São Paulo: Saraiva, 1980.

MIRABETE, Júlio Fabbrini. Processo penal. 18. ed. São Paulo: Atlas, 2006.

NORONHA, Edgard Magalhães. Curso de Direito Processual Penal. 24. ed., São Paulo: Saraiva, 1996.

NUCCI, Guilherme de Souza. Manual de processo e execução penal. São Paulo: Revista dos Tribunais, 2005. 
PINTO, Ronaldo Batista, Prova Penal segundo a jurisprudência, São Paulo, Saraiva, 2000.

PITOMBO, Cleunice Valentim Bastos e outros. Publicidade, ampla defesa e contraditório no novo interrogatório judicial. Boletim do IBCCRIM, ano 11, n. 135, p. 2, fev. 2004.

PITOMBO, Cleunice Valentim Bastos. Considerações iniciais sobre a lei 11.690/08. Disponível em <http://www.ibccrim.org.br>. Acesso em 18jul2008.

PORTO, Herminio Alberto Marques, Júri - Procedimento e Aspectos do Julgamento Questionários, 4. ed., São Paulo, Revista dos Tribunais, 1984.

PRADO, Geraldo Sistema acusatório: a conformidade constitucional das leis processuais penais. Rio de Janeiro: Lumen Juris, 2001.

SANTOS, Moacyr Amaral. Prova judiciária no cível e no comercial, vol. I, 2. ed., São Paulo: Max Limonad, 1962.

SARLET, Ingo Wolfgang. A eficácia dos direitos fundamentais. 2. ed., Porto Alegre: Livraria do Advogado, 2001.

SILVA, Marco Antonio Marques da. Acesso à justiça penal e Estado Democrático de Direito.

São Paulo: Juarez de Oliveira, 2001.

TORNAGHI, Hélio. Curso de processo penal. 7. ed. São Paulo: Saraiva, 1990.

TOURINHO FILHO, Fernando da Cosa. Processo penal. Vol. 1, 25. ed. São Paulo: Saraiva, 2003.

ZILLI, Marcos. O pomar e as pragras. Boletim do IBCCRIM, ano 16, n. 188, julho 2008. 